DOI: $10.15421 / 272021$

УДК 94:323](477+(47+57))»1835/1896» (092)

\title{
С. Світленко
}

\author{
Дніпровський національний університет імені Олеся Гончара, \\ проспект Гагаріна, 72, м. Дніпро, 49010, Україна
}

\section{УКРАЇНСЬКИЙ НАРОДОЛЮБЕЦЬ ОЛЕКСАНДР ТИЩИНСЬКИЙ}

\author{
E-mail: svitlenko@gmail.com \\ ORCID: 0000-0003-3313-9036 \\ ResearcherID: R-5856-2017
}

Анотація. Метою статті є висвітлення формування і становлення особистості О. А. Тищинського (1835-1896) як українського народолюбця другої половини XIX ст. Методами дослідження стали історико-генетичний, історико-типологічний, персоналі- стичний. Джерела: архівні документи з фондів III відділу Власної його імператорської величності канцелярії та Особливого присутствія Правительствуючого Сенату Російської імперії, опубліковані спогади М. М. Грінченко та А. В. Верзиліва, С. Ф. Русової, автобіографічні нотатки П. С. Сфименка, творчі матеріали О. А. Тищинського, епістолярії О. Я. Кониського, А. П. Свидницького тощо. Основні результати полягають у тому, що автор з'ясував, що формування світогляду Олександра Тищинського відбувалося під впливом кількох важливих ідейних чинників, зокрема ліберальних ідей оновлення суспільства на основі утвердження конституційного способу правління; поглядів радикальної демократії, які популяризувалися «Колоколом» О. І. Герцена та М. П. Огарьова; українських народолюбних впливів, які спричинили формування зацікавленості українським фольклором і письменством, а особливо поезією Тараса Шевченка. Діяльність О. А. Тищинського як українського народолюбця зародилася в період його участі в Харківсько-Київському таємному товаристві (1856-1860), а утвердилася на початку 1860-х рp. - у часи діяльності в Чернігівській українській громаді. Як український національний демократ, О. А. Тищинський займався педагогічною, публіцистичною та громадською національно-культурницькою діяльністю, хоча його радикально-демократичні симпатії обумовлювали зв'язки з російськими землевольцями. У 1870-1880-х рр. український діяч був серед найактивніших організаторів Чернігівської громадської книгозбірні та книгарні, відстоював інтереси народу в лавах Чернігівського повітового земства, сприяючи поступу народної освіти, охорони здоров'я тощо. У 1890-х рр. О. А. Тищинський належав до тих діячів, які відновили Чернігівську українську громаду. Стислі висновки. Доведено, що О. А. Тищинський, незважаючи на впливи російської радикальної демократії, сформувався як діяч українського національно-демократичного руху, який від початку 1860-х і до середини 1890-х рр. належав до найпомітніших й найавторитетніших українських народолюбців Чернігівщини, зробив свій внесок у розвиток українського національного культурництва в цьому краї. Практичне значення статті в тому, що ії матеріал представлятиме інтерес для студентів, аспірантів, докторантів та фахівців-істориків у процесі вивчення етнонаціональної та суспільно-політичної історії України XIX ст. Орихінальність статті полягає в осягненні маловивчених аспектів світогляду й діяльності українського діяча. Наукова новизна в актуалізації життя та діяльності O. А. Тищинського як українського національного демократа другої половини XIX ст. Tun cmammi: описово-аналітичний.

Ключові слова: російський визвольний рух, таємне товариство, український національний рух, українська громада, повітове земство. 


\title{
S. Svitlenko
}

\author{
Oles Honchar Dnipro National University, Gagarin Avenue, 72, Dnipro, 49010, Ukraine
}

\section{UKRAINIAN NARODOLYUBETS OLEKSANDR TYSHCHYNSKY}

Abstract. The purpose of the article is to highlight the formation of the personality of O. A. Tyshchynsky (1835-1896) as a Ukrainian patriot of the second half of the XIX century. The research methods were historical-genetic, historical-typological, personalistic. Sources: archival documents from the funds of the Third Department of His Imperial Majesty's Chancellery and the Special Presence of the Ruling Senate of the Russian Empire, published memoirs of MM Grinchenko and A. V. Verzyliv, S. F. Rusova, autobiographical notes of P. S. Efimenko, creative materials A. Tyshchynsky, epistolary by O. Ya. Konysky, A. P. Svydnytsky, etc. The main results are that the author found that the formation of the worldview of Olexander Tyshchynsky was influenced by several important ideological factors, including liberal ideas of renewal of society based on the establishment of the constitutional image of government; views of radical democracy, which were popularized by the «Kolokol» of O. I. Herzen and M. P. Ogarev; Ukrainian patriotic influences, which led to the formation of interest in Ukrainian folklore and literature, and especially the poetry of Taras Shevchenko. O. A. Tyshchynsky's activity as a Ukrainian narodolyubets originated during his participation in the Kharkiv-Kyiv Secret Society (1856-1860), and was established in the early 1860s during his time in the Chernihiv Ukrainian community. As a Ukrainian national democrat, O. A. Tyshchynsky was engaged in pedagogical, journalistic and public national-cultural activities, although his radical-democratic sympathies conditioned ties with Russian landowners. In the 1870s and 1880s, the Ukrainian activist was among the most active organizers of the Chernihiv Public Book Collection and Bookstore. defended the interests of the people in the ranks of the Chernihiv district zemstvo, promoting the progress of public education, health care, etc. In the 1890s, O. A. Tyshchynsky was one of those figures who restored the Chernihiv Ukrainian community. Brief conclusions. It is proved that O.A. Tyshchynsky, despite the influence of Russian radical democracy, was formed as a figure of the Ukrainian national democratic movement, which from the early 1860 s to the mid-1890s belonged to the most prominent and authoritative Ukrainian patriots of Chernihiv region, made his contribution to the development of Ukrainian national culture in this region. The practical significance of the article is that its material will be of interest to students, graduate students, doctoral students and historians in the study of ethno-national and socio-political history of Ukraine in the XIX century. The originality of the article lies in the comprehension of little-studied aspects of the worldview and activity of the Ukrainian figure. Scientific novelty in the actualization of the life and work of O. A. Tyshchynsky as a Ukrainian national democrat of the second half of the XIX century. Article type: descriptive-analytical.

Keywords: Russian liberation movement, secret society, Ukrainian national movement, Ukrainian community, county zemstvo.

Постановка проблеми. Проблема становлення української національної ідентичності $€$ вельми важливою для сучасного суспільства незалежної України. Адже від її успішного розв'язання залежить завершення процесу утвердження української модерної нації, а це один із суттєвих чинників вдалої трансформації нашого соціуму й політикуму, економіки й культури від пострадянської країни до суверенної й незалежної України не тільки де-юре, а й де-факто. Звичайно, на цьому, як виявилося, тернистому шляху є безліч труднощів і проблем. Одна з них - відродження і збереження історичної пам'яті в контексті процесу українського націотворення, пізнання історичного досвіду попередніх поколінь свідомих українців та вивчення історичних уроків їхньої діяльності.

У цьому контексті особливої актуальності набуває проблема формування української демократичної еліти. 3 цього погляду є вельми цікавим і повчальним життєвий досвід покоління українських народолюбців - вітчизняних демократів, які від середини XIX до початку XX ст. відігравали важливу роль у пошуку змістів української національної ідеї та українського націотворення. I слід зазначити, що, хоча історики вже чимало зробили задля розробки цієї проблематики, велика кількість персоналій українських народолюбців, особливо діячів другого плану, які поміж тим 
були відомими на регіональному рівні, залишається ще недостатньо дослідженою й малознаною навіть серед вузького кола фахівців. Одним із них є Олександр Амфіанович Тищинський (1835-1896), один із помітних українських діячів на Чернігівщині другої половини XIX ст.

Історіографія. Постать свідомого українця О. А. Тищинського малознана для сучасного читача, що й не дивно, бо його життя та діяльності стосується порівняно нечисленна література та опубліковані джерела. Серед найбільш докладних опублікованих першоджерел, які містять цікаву й вірогідну інформацію про О. А. Тищинського, слід назвати спогади М. М. Грінченко та А. В. Верзиліва про Чернігівську українську громаду [10], П. С. Єфименка [12] та Софії Русової [17]. В українській радянській історіографії постать О. А. Тищинського спеціально не вивчалася. Хіба що можна назвати монографію Федора Ястребова, присвячену революційним демократам в Україні другої половини 50-х - початку 60-х рр. XIX ст., у якій неодноразово згадувався й О. А. Тищинський і містилися цікаві дані про його погляди та діяльність у період Харківсько-Київського таємного товариства 1856-1860 pp. Звичайно, за тих історичних умов автор зробив наголос на його діяльності в контексті загальноросійського визвольного руху, хоча не обійшов увагою той факт, що в паперах діяча було знайдено «ряд прокламаций возмутительных на украинском языке» [26, с. 146]. Деяких важливих аспектів пізнішої діяльності О. А. Тищинського торкалися М. Є. Сиваченко та О. А. Деко у своїй книзі «Леонід Глібов. Дослідження і матеріали» (Київ, 1969). У дослідженні йшлося про причетність Олександра Амфіановича до справи землевольця Івана Андрущенка (1863) та про його спробу разом Миколою Константиновичем заснувати газету «Черниговский листок» (1872) [20].

Поміж досліджень останнього часу варто назвати нарис Л. В. Студьонової про Чернігівське повітове земство, якому О. А. Тищинський віддав багато своїх життєвих сил [21]; змістовні статті українських літературознавців: В. І. Дудка - про «ранній» період життя та діяльності О. А. Тищинського [11] та Г. В. Самойленка - про О. А. Тищинського як друга видатного українського байкаря Л. І. Глібова [18]. Утім, в історіографії немає жодного дослідження, яке б розкривало формування й становлення світогляду та діяльності Олександра Амфіановича як українського діяча. Мета даної статті полягає у висвітленні особистості О. А. Тищинського як українського народолюбця.

Джерельну основу даної розвідки становлять архівні документи з фондів III відділу Власної його імператорської величності канцелярії та Особливого присутствія Правительствуючого Сенату (Ф. 109 та 112 Государственного архива Российской Федерации), опубліковані спогади М. М. Грінченко та А. В. Верзиліва, автобіографічні нотатки П. С. Єфименка, творчі матеріали О. О. Тищинського, епістолярії О. Я. Кониського, А. П. Свидницького тощо.

Виклад основного матеріалу. Олександр Амфіанович Тищинський народився 4 квітня 1835 р. на Чернігівщині, в с. Голубичи Городянського повіту, в сім’ї оберофіцера, дворянина, який служив у Чернігівській казенній палаті. Помер його батько, Амфіан Тищинський, в 1847 р., залишивши у спадок невеликий родинний маєток, де проживало до 100 душ селян. Із слідчих показів О. А. Тищинського відомо, що після смерті батьків О. А. Тищинський разом зі своїми трьома братами та чотирма сестрами став спадкоємцем батьківської спадщини [1, л. 545 об.; 14, с. 138].

31847 р. Олександр виховувався в Чернігівській гімназії, але курсу не закінчив. У 1856 р. юнак переїхав до Харкова, де вступив до місцевого Ветеринарного училища, але навчався там не більше трьох місяців. Затим він усе таки реалізував свою мрію, вступивши в серпні 1857 р. на медичний факультет Харківського університету [1, л. 545 об.; 10, с. $464 ; 11$, с. 76,79$]$.

У харківський студентський період у світогляді Олександра Тищинського відбувалися істотні зміни. Як він зізнавався у листі до свого гімназичного товариша, а затим студента Петербурзького університету Н. Н. Рашевського від 21 січня 1858 р., коло нових знайомств сприяло тому, що його соціальні та релігійні переконання багато в чому розходилися з попередніми, гімназичними. У новому для себе студентському 
середовищі Олександр Тищинський навчився «думати по людськи», «піклуватися і не забувати інших, близьких наших...» [22, с. 11-12].

Друга половина 50-х pp. XIX ст. характеризувалася наростанням опозиційного й революційного рухів, до яких усе активніше залучалася студентська молодь. Не став винятком і Олександр Тищинський, який вже приблизно у квітні - травні 1856 p. познайомився в Харкові з Яковом Бекманом, Петром Сфименком, Петром Завадським, Володимиром Івковим, Митрофаном Муравським.

У цьому студентському середовищі спостерігалися помітні українські симпатії, за своїм духом близькі Олександру. Прикметно, що в цей період Петро Завадський почав писати україномовну прокламацію «Відозва до українців». Олександр Тищинський взяв участь у редагуванні цієї відозви, зберігав їі у своїх паперах $[26$, с. 133, 134, 146]. В ній містилося спростування царського Маніфесту про мир і заклик до зміни способу правління в Росії [1, л. 493].

Із слідчих показів Якова Бекмана від 5 травня 1860 р. стає зрозумілим, що його ідея започаткувати таємне товариство спочатку не знайшла підтримки у його знайомих: Петра Єфименка, Петра Завадського, Митрофана Муравського, Олександра Тищинського та Володимира Івкова. Особливо чинили спротив Митрофан Муравський та Олександр Тищинський. Лише згодом, очевидно, восени 1856 р. Якову Бекману за допомогою Миколи Раєвського вдалося схилити до цього своїх товаришів [1, л. 422].

На початку серпня 1856 р. Олександр Тищинський оселився в Пісках, районі Харкова. Через певний час у тому самому місці зняли квартиру студенти П. С. Єфименко та П. В. Завадський, котрі вирізнялися своїм критичним мисленням. Їхні бесіди з Тищинським незабаром набули відверто ліберального характеру. Олександр зацікавився обміном думок настільки, що став брати ліберальні твори й переписувати їх у себе на квартирі. В цьому контексті цікаві деякі рукописні матеріали, знайдені згодом у О. А. Тищинського. Це, зокрема, стаття «Голос из села», де йшлося про невдоволення українців царем і урядом. Антиурядову спрямованість мала й стаття «Русскому воинству в Польше».

Окрім того, в паперах Олександра Тищинського зберігалися писані його рукою дві пародії на царські маніфести та два листа, в яких давалася негативна оцінка царського уряду, а Росія називалася «варварською країною». Як бачимо, зав'язавши знайомства 3 деякими опозиційними харківськими студентами, Олександр став читати, переписувати і зберігати безцензурні матеріали, що складало політичний зміст діяльності таємного товариства [1, л. 492, 493; 22, с. 20$]$.

Через певний час П. В. Завадський запросив Олександра на перші таємні збори студентів, які відбулися 13 листопада 1856 р. Незадовго до цієї дати О.А. Тищинський приєднався до таємного товариства ідейно. Учасники зібрання на квартирі П. С. Єфименка та П. В. Завадського, в тому числі Олександр Амфіанович, прослухали промову Миколи Раєвського. Оратор доводив, що прагнення до встановлення конституційного правління $\epsilon$ найбільш сучасним. Затим молоді люди обговорили необхідність розробки статуту таємного товариства. Наприкінці листопада Олександр Тищинський відвідав другі таємні збори, де їх учасники ухвалили статут. Тоді ж обрали й керівників товариства: президентом став Микола Раєвський, віце-президентом - Яків Бекман, секретарем - Петро Завадський. Саме ці діячі були співавторами статуту.

За пропозицією Миколи Раєвського для прикриття таємного товариства створили й літературне. В його межах зазвичай читалися твори відомих ліберальних письменників та журнали. Бібліотекарем товариства працював Митрофан Муравський. Втім, як зазначав Петро Завадський, це було не літературне, а політичне товариство з вузьким колом осіб, до складу якого входило спочатку сім, а затим 13 дійсних членів. Метою таємного товариства, яке об'єднало як Літературне товариство, так і «Пасквільний комітет», був загальний переворот в імперії, починаючи з визволення селян $[1$, л. 329 , 330, 331, 403, 441 об., 456, 545; 22, с. 19-21, 71].

Із додаткових слідчих показів Митрофана Муравського видно, що збори таємного товариства тривали й у січні - першій половині лютого 1857 р. При цьому учасники 
конспіративних зустрічей, під впливом пом'якшення цензури, підготовки селянської реформи та інших реформістських кроків Олександра II, стали співчутливіше ставитися до мирних способів оновлення суспільства і з меншою довірою - до насильницьких революцій. Наприкінці 1857 р. не стало й залишків колишніх радикальних намірів. I тут слід вказати, що спочатку, в 1856 р., між учасниками точилися дебати навіть про знищення імператорської сім’ї. Проте Олександр Тищинський, за своїми свідченнями, в 1857 р. не брав участі в таємних зібраннях. Причину цього він пояснював підготовкою до іспиту в університет. Свого часу ще Ф. О. Ястребов, аналізуючи склад учасників Літературного товариства, помітив, що лише Петро Єфименко чітко називав Олександра Тищинського його членом, а Митрофан Левченко, Веніамін Португалов, Віктор Хлопов та Андрій Шимков не пригадували його участь, хоча, можливо, він входив до категорії «та інші», «та багато інших», тобто другорядних діячів [1, л. 332-333, 455-457; 26, c. $172-173]$.

У 1857 р. О.А. Тищинський став навчатися на медичному факультеті Харківського університету, де в середовищі опозиційно налаштованої студентської молоді його ідейні погляди кристалізувалися все більше. Свідченням цього є листування Олександра 3 колишнім товаришем по Чернігівській гімназії, а затим студентом Петербурзького університету Н. Н. Рашевським наприкінці 1857 - на початку 1858 р. Так, лист О.А. Тищинського до свого адресата від 21 січня 1858 р. переконує, що його опозиційний світогляд формувався внаслідок критичного осмислення дійсності, на основі власного життєвого досвіду й утверджувався під впливом несприйняття існуючої в імперії системи середньої й вищої освіти, що не вчила відрізнити істину від брехні. Втім, допитливий Олександр розумів, що причина не в гімназіях чи університетах, а в чиійсь волі, котра «зверху вниз все тисне, тисне...». Безперечно, свою роль у формуванні критичного мислення відігравала російська прогресивна література, той самий М. Є. СалтиковЩедрін, який уїдливо висміював вади існуючого суспільного ладу [22, с. 11-12].

Формування світогляду Олександра Тищинського відбувалося також під впливом кількох важливих ідейних чинників. По-перше, на наш погляд, значну роль відігравали ліберальні ідеї оновлення суспільства на основі утвердження конституційного способу правління, що ставило на меті таємне товариство, до лав якого залучився Олександр. Подруге, не менш суттєву роль відігравали ідеї радикальної демократії, які продукувалися «Колоколом»-рупором «лондонських пропагандистів» О. І. Герцена та М. П. Огарьова. По-третє, істотне значення мали й українські народолюбні впливи, які спричинили формування зацікавленості Олександра Тищинського українським фольклором і письменством, а особливо поезією Тараса Шевченка.

Уже в харківський період своєї діяльності О. А. Тищинський редагував одну 3 україномовних антиурядових прокламацій. На користь його українолюбних уподобань свідчить лист від 27 березня 1857 р. до редактора «Черниговских Губернских Ведомостей» О. В. Шишацького-Ілліча, автора першої частини збірки «Українська квітка» (Чернігів, 1856). У листі Олександр навів уривки з поширюваної у списках «Розритої могили» Тараса Шевченка, піддав гострій критиці автора зазначеної збірки, обвинувачуючи його в перевертництві, яке допомагає в Україні «москалеві господарювати» [14, с. 76-77].

Можна з великою долею вірогідності стверджувати, що значний вплив на Олександра Тищинського вже в студентські роки мав один з його найближчих однодумців Петро Єфименко, який згадував, що ще в гімназії прочитав «Кобзар» Т. Г. Шевченка і «пролив потоки сліз». Під враженням від цієї книжки він почав записувати народні прислів'я, пісні тощо й таким чином перетворився на «самодільного українського народника і етнографа», який з інтересом читав книжки з історії та літератури, що описували Україну. В 1855 р. П. С. Сфименко натрапив у Харківському університеті на український гурток медика В. М. Нельговського, який збирався певний час [13, арк. 1 зв.; 12, с. 40, 41]. Такі самі зацікавленості опанували помислами й діями молодого Тищинського. 
У квітні 1858 р. О.А. Тищинський брав участь у масових студентських заворушеннях, одержав «Височайшу» догану і разом зі своїми товаришами по таємному товариству восени того самого року перевівся до Університету Св. Володимира в Києві, де навчався спочатку на медичному, а згодом на правничому факультеті. В київській період своєї громадської діяльності він активно спілкування зі своїми однодумцями, знайомими по Харкову, зокрема 3 Яковом Бекманом, Петром Сфименком, Митрофаном Муравським, котрі виказували українські симпатії [1, л. 546; 10, с. 464; 22, с. 32; 11, c. 77).

Крім зазначених осіб, до кола знайомих Олександра Тищинського, котрі переїхали iз Харкова до Києва, належали Снкуватий, Леон Зеленський, Іона Кацен, Лебедєв, Веніамін Португалов, Григорій Розен, Леонід Россинський, Яків Шмулевич. До цього ж до зазначеного кола увійшли й київські студенти Володимир Антонович, Феодосій Вороний, Інокентій Патлаєвський, Кременський, Пигулевський, Цибульський та ін., які об'єдналися в літературний гурток. Дещо згодом до них пристали Міллер, Очкін та Шкуратов. Тоді у Феодосія Вороного виникла ідея заснувати недільні школи, що вже восени 1859 р. почала втілюватися в життя. Започаткувавши недільні школи у приміщенні Києво-Подольського дворянського училища, а затим у Старому місті та на Новому строєнії, українські народолюбці стали перетворювати їх на осередки своєї діяльності в народі [1, л. 386].

Саме в київський період остаточно виявилися українознавчі зацікавленості та українолюбна світоглядна спрямованість О. А. Тищинського. 3 показань П. С. Сфименка від 28 квітня 1860 р. дізнаємось, що навесні 1859 р. О. А. Тищинський збирав пам'ятки народної української («південноруської») словесності для друкування їх у «Черниговских Губернских Ведомостях». Здебільшого вони репрезентували народні заклинання й замовляння. Ці заняття були близькі П. С. Єфименку, а тому він надав своєму однодумцю кілька доповнень і пояснень. Водночас Петро Савич дорікав О. А. Тищинському, очевидно це було в 1859 р., що той не брав участі в розповсюдженні творів, студентських заходах тощо. Очевидно, це можна пояснити тим, що український народолюбець захопився збиранням українських пам'яток [1, л. 349-350].

Це й не дивно, бо в Києві наприкінці 50-х рр. ХІХ ст. кристалізувалося ядро української національно-демократичної молоді. Центром тяжіння молодих свідомих українців стала студентська квартира, знана між товаришами як «Малоросія». 3 серпня 1859 р. там проживали українські народолюбці Петро Єфименко та Анатолій Свидницький. 3 останнім у цьому помешканні познайомився і зблизився Олександр Тищинський. Відомо, що на початку 1860 р. разом з ним квартирували студенти Університету Св. Володимира Петро Єфименко та Гавриїл Стрижевський.

У «Малоросію» нерідко заходили й такі патріотично налаштовані київські студенти, як Володимир Антонович, Михайло Малашенко, Тадей Рильський; заїжджав проїздом із Петербурга Павло Чубинський. Всі згадані діячі являли собою переконаних українських народолюбців. Це середовище цілком певно впливало й на Олександра Тищинського $[12$, с. $41 ; 22$, с. $32 ; 11$, с. 77$]$.

У зазначений період О. А. Тищинський сформувався в українського громадського діяча, котрий визнавав себе українцем. У листі до свого товариша по Чернігівській гімназії Н. Н. Рашевського від 21 січня 1858 р. він стверджував: «...Я малорос, у якого завжди почуття переважає над свідомістю». Він завжди поважав людей за їхні щирі переконання, навіть тоді, коли вони розходилися з його власними. Українському народолюбцю не подобалися люди, у яких справи не сходилися з їхніми словесними деклараціями. О. А. Тищинський дотримувався життєвого принципу: «Все добре, що помірковано і шляхетно» [22, с. 11, 12; 1, л. 374-375].

Українолюбні симпатії виявилися вже в перших публікаціях О. А. Тищинського на шпальтах «Черниговских Губернских Ведомостей», де після появи нового редактора Г. І. Паливоди, до речі, учасника місцевої української громади, стали з'являтися україномовні твори та українознавчі матеріали. До них належить аналітична стаття 
О. А. Тищинського «Об украинских пословицах и поговорках» 3 приводу збірника П. С. Єфименка «Украинские пословицы и поговорки» (ЧГВ, 1859. №№ 6-14). Там само публікувалися українською мовою зібрані ним у Городнянському повіті народні оповідання, прислів'я і приказки [11, с. 77; 20, с. 21].

Поряд із тим слід констатувати, що в цей період О. А. Тищинський водночас перебував на орбіті діяльності Харківсько-Київського таємного товариства, учасники якого знаходились під впливом ідей російської революційної демократії, особливо О. І. Герцена та М. П. Огарьова. Олександр Тищинський приділяв головну увагу переписуванню заборонених видань: сатиричних пародій на царські маніфести 1856 та 1857 рр., статей з герценовського «Колокола», революційних відозв тощо.

Антиурядова діяльність Олександра Тищинського була припинена його арештом 1 лютого 1860 р. Голова Петербурзької слідчої комісії дійшов висновку, що в жодного із заарештованих осіб не знайдено такої кількості виписок цього роду, як у О. А. Тищинського. Слідство у цій справі дізналося про листування діяча 3 представниками радикально-демократичної молоді Сум та Чернігова, яке ставило на меті розповсюдження «відозв Іскандера (О. І. Герцена. - Aвm.)». Все це дало підстави звернути на нього увагу і встановити за ним нагляд [1, л. 379, 492-493, 599; 22, с. 73]. За трьома законами Російської імперії всі 15 заарештованих, у т. ч. О. А. Тищинський, підлягали за участь у таємному товаристві смертній карі. Проте Олександр II наказав вирішити справу «адміністративним порядком», розподіливши всіх заарештованих на три категорії. Олександр Амфіанович належав до осіб, котрі проходили за другою категорією, яким цар наказав обмежитися утриманням у фортеці i «суворим навіюванням» [22, с. 76].

За участь у таємному товаристві О. А. Тищинський був ув'язнений у сумнозвісному Алексєєвському равеліні Петропавловської фортеці Санкт-Петербурга, звідки він звільнився 24 червня 1860 р. Наступного дня його відправили із III відділення Власної його імператорської величності канцелярії до Дерпта. У фонді ІІІ відділення відклалися папери О. А. Тищинського: свідоцтво про народження, про хрещення і дворянство, а також дві пачки паперів, що відбивали участь Олександра Амфіановича в ХарківськоКиївському таємному товаристві [2, арк. 98-99; 4, л. 1; 6, 39 л.].

Царська влада дозволила Олександру продовжити освіту на юридичному факультеті Дерптського університету, але під секретним поліцейським наглядом. Фактично цей нагляд був потрійним, адже, крім поліції, за опальним студентом наглядало університетське начальство і жандарми. Під час навчання він належав до найпомітніших і найрадикальніших студентських діячів, входив до складу університетського студентського гуртка, що заснував студентську касу, загальнодоступну бібліотеку, недільну дівочу школу. Перебуваючи в Дерптському університеті, студент Тищинський підтримував старі контакти з однодумцями в Києві та Харкові, продовжував публіцистичні дописи. Зокрема, О. А. Тищинський опублікував у газеті «Московские ведомости» статтю «О малорусских азбуках», що промовисто свідчить про його українолюбні інтереси [10, с. 464; 11, с. 78].

Проте завершити університетський курс Олександру не довелось. Внаслідок гострого конфлікту між проректором університету і Олександром Тищинським, який відмовився виконати розпорядження університетського начальства поголити бороду, студента очікував карцер. Але вільнолюбець заявив, що не буде підкорятися й чинитиме всілякий спротив. Тоді проректор негайно призначив засідання університетського суду, який виключив О. А. Тищинського із лав студентів без права продовження освіти в будьякому університеті. Міністр народної освіти С. В. Путятін підтримав таке рішення. На колишнього студента чекала висилка 3 Дерпта до Чернігова під поліцейський нагляд [3, л. 73, 98, 99, 146, 299-300; 2, с. 300].

Вже зі студентським часів Олександр Тищинський переймався не тільки ідеями російської революційної демократії, а й українського народолюбства і став свідомим українцем. Він товаришував із рядом українських громадських діячів, зокрема Володимиром Антоновичем, Леонідом Глібовим, Петром Єфименком, Павлом 
Чубинським, дописував до петербурзького часопису «Основа» та «Черниговского листка», відомими своїм українським спрямуванням, і навіть зав'язав зносини з галицькими українцями, добував звідти книжки, підтримував матеріально прогресивні закордонні видання [10, с. 465].

30 серпня 1861 р. Олександр Тищинський покинув Дерпт. Спочатку він направився до Москви, де зробив невдалу спробу вступу до університету. Перебуваючи у Москві, він отримав у Свгена Андрущенка примірники герценівського «Колокола» та «Полярной звезды» для передачі в Чернігові його брату Івану Андрущенку, пов'язаному 3 радикальним гуртком московських студентів П. Аргіропуло та П. Зайчневського, а нещодавно прибув у місто на Десні на службу [20, с. 10-11, 13).

21 жовтня того самого року опальний студент приїхав до Чернігова, а затим до рідного маєтку в Голубичах. Але діяльна натура вимагала скорішої праці. Вже на початку 1862 р. О. А. Тищинський знайшов місце роботи в селі Макишино Городнянського повіту, де влаштувався домашнім учителем в родині поміщика П. Чичеріна [11, с. 78]. Вчителюючи в Макишиному, український народолюбець бував у Чернігові, де підтримував добрі відносини з I. О. Андрущенком, Л. І. Глібовим, І. П. Дорошенком, М. О. Константиновичем, О. В. Марковичем та іншими діячами [18, с. 52].

Поряд із педагогічною діяльністю, О. А. Тищинський продовжив свої заняття публіцистикою. Олександр Амфіанович став дописувачем першого українського літературно-наукового журналу «Основа», що видавався зусиллями українських народолюбців В. М. Білозерського, М. І. Костомарова та П. О. Куліша в 1861-1862 pp. у столиці імперії. Перу О. А. Тищинського, який писав під криптонімом Леся -ій, належать три кореспонденції з Городнянського повіту, що вийшли у світ у проміжку між 15 грудня 1861 р. та 25 червня 1862 р. В цих дописах порушувалися актуальні питання педагогіки й діалектології. Важливо, що, досліджуючи городнянські говірки, український народолюбець стверджував про ефективність навчання в рідному краї, якщо воно вестиметься не російською, а української мовою. Окрім того, українського публіциста-народолюбця цікавили й актуальні питання втілення в життя аграрної реформи 1861 р., зокрема капіталізація села, формування сільського самоврядування, проведення межування землі тощо [11, с. 78-79].

За умов припинення виходу у світ часопису «Основа» О. А. Тищинський продовжив свою публіцистичну діяльність на шпальтах місцевої газети «Черниговский листок», що видавалася в 1861-1863 рр. Олександр Амфіанович, належачи до головних співробітників часопису, став автором декількох публікацій, зокрема «Седневская Ильинская ярмарка: (Письмо в редакцію)», «3 понадснів'янського села», «Мысль об устройстве сельских почт», «Образец заботливости охранения лесов в Черниг[овском] уезде», «Из села Макишина Город[ицкого] уезда». Як бачимо, більшість цих публіцистичних дописів були російськомовними, проте був і виняток - україномовна стаття «З понадснів'янського села». В. І. Дудко зазначав докладність цієї публіцистичної статті, яка освітлювала сторінки історичного минулого, народні звичаї та реалії сьогодення. Ці та інші публікації, які з'являлися в газетній рубриці «Новости, вести и слухи», були спрямовані на висвітлення проблем та пошуків засобів поліпшення життя простих людей у краї [25, с. $450-451 ; 11$, с. 80$]$.

Поряд з педагогічною та публіцистичною діяльністю, О. А. Тищинський не полишав громадської праці і став помітним діячем Чернігівської української громади, учасники якої розвивали національне культурництво: поширювали популярні книжки для народу, читали твори Тараса Шевченка, організовували недільні школи, влаштовували спектаклі, співали народні пісні, вдягалися в народне вбрання, колекціонували речі української старовини тощо [20, с. 12]. О. А. Тищинський належав до активних учасників Чернігівської театральної трупи «Товариство кохаючих українську мову». Разом із Л. І. Глібовим, М. А. ВербицькимАнтіохом, О. М. Лазаревським, О. В. Марковичем, С. Д. Носом та іншими народолюбцями 
він брав участь у театральних виставах, допомагав Л. І. Глібову підбирати акторів, опікувався налагодженням режисури [19, с. $52 ; 18$, с. 204$].$

Характерно, що в той час у лавах Чернігівської української громади намітилися дві ідейні тенденції. Превалювало помірковане крило на чолі з «курінним отаманом» Степаном Носом, яке обмежувалося культурницько-просвітницькими заходами. Секретна записка Чернігівського жандармського штабс-офіцера зафіксувала, що С. Д. Ніс приймав на своїй квартирі всіх, хто був одягнутий «в малоросійський костюм», і виїжджав із ними за місто, де народолюбці розкладали багаття, жарили на паличках сало, декламували вірші Т. Г. Шевченка, співали українські пісні. Подібні зустрічі користувалися популярністю, а тому чисельність відвідувачів «куреня», як називалась квартира «провідника товариства малорософілів», постійно збільшувалася [7, л. 569-569 об.].

Але серед чернігівських громадівців були й радикальніші діячі, які не остерігалися зав'язати контакти з представником російської таємної організації «Земля і воля». Звісно, між ліберально-демократичними й радикально-демократичними діячами не існувало якоїсь чіткої межі, яка б заважала підтриманню добрих людських стосунків. Так, наприклад, український байкар Леонід Глібов мав тривали і дружні стосунки з Олександром Тищинським, а також співпрацював з Іваном Андрущенком у «Черниговском листке» в 1861 р. та листувався з ним у 1862 р., тобто не цурався діячів радикально-демократичного спрямування.

Коли Іван Андрущенко, вже будучи учасником «Землі і волі», вдруге приїхав до Чернігова влітку 1863 р., він мав бесіди з низкою місцевих громадівців, зокрема з О. А. Тищинським, О. М. Білозерським, І. О. Маслаковцем та ін.; розповсюджував підпільну літературу. Особливо слід згадати про вечірку 8 липня 1863 р. на квартирі О. М. Білозерського в якій, крім господаря, були I. О. Андрущенко, С. Д. Ніс та О. А. Тищинський. На цьому зібранні землеволець інформував українських народолюбців про таємну організацію «Земля і воля», розкривав гострі політичні проблеми, порушував злободенне польське питання, знайомив з підпільними відозвами.

Коли учасники вечірки глупої ночі перейшли на квартиру С. Д. Носа і продовжили обговорення проблем визвольного руху, О. А. Тищинський виявив винятковий інтерес до нелегальної літератури, привезеної І. О. Андрущенком, а на другий день взяв 10 примірників землевольських видань 3 метою розповсюдження в Городницькому повіті. Серед них була відозва «Землі і волі» «Свобода», прокламації «Что нужно народу?» та «Долго давили вас, братцы» [8, л. 1-1об.; 9, л. 226-229; 20, с. 14, 19-27, 31-38, $50-52,104 ; 24$, с. 35].

Ці контакти були виявлені й почалися арешти. До справи про розповсюдження нелегальних прокламацій С. Д. Носом та І. О. Андрущенком було притягнуто 39 осіб, у тому числі й О. А. Тищинський $[10$, с. $464 ; 16$, с. 292]. Наприкінці вересня 1863 р. в його маєтку в с. Голубичі зробили трус. Незабаром громадського діяча було ув'язнено в Петропавловській фортеці. Після звільнення 18 травня 1864 р. Олександр Амфіанович повернувся на Батьківщину, де перебував під суворим наглядом поліції до 1872 р. [8, л. 201; 5, л. 642].

Незважаючи на опалу, з дозволу Сенату і за наказом міністра з 20 вересня 1864 p. О. А. Тищинського було взято на службу до канцелярії Чернігівського губернатора. Нове призначення чиновником у губернаторську канцелярію пояснюється тим, що можновладці в такий спосіб прагнули краще тримати його в полі свого зору. Однак справа, за якою проходив Олександр Тищинський, була остаточно розв’язана Сенатом, а затим затверджена Державною радою і самим царем лише в 1866 р. При цьому, згідно з постановою Правительствуючого Сенату і указом Олександра II від 6 квітня 1866 р. український народолюбець був змушений ще відсидіти два місяці в ув'язненні [24, c. $36 ; 18$, с. 53$]$.

Однак здібності Олександра Амфіановича не залишилися непоміченими. У 1869 p. він став старшим помічником правителя канцелярії губернатора й отримав дозвіл 
редагувати неофіційний додаток («Особое прибавление») до «Черниговских Губернских Ведомостей», де вміщував і деякі свої дописи [10, с. 464].

У жовтні 1872 р. О. А. Тищинський та М. О. Константинович (вчитель Чернігівської гімназіi) звернулися з проханням до Чернігівського губернатора О. О. Панчулідзева дозволити видавати з 1 січня 1873 р. газету «Черниговский листок». Аналіз програми цього видання свідчить, що його ініціатори сподівалися широко висвітлювати сюжети 3 місцевого громадського життя, публікувати статті з історії, археології, статистики, етнографії та літератури краю. Саме ці теми постійно цікавили тодішніх українських народолюбців-культурників.

Прохання чернігівських народолюбців породило листування, до якого залучилися Чернігівський губернатор, Міністерство внутрішніх справ, III відділення Власної його імператорської величності канцелярія та Головне управління у справах друку. В результаті Олександр Тищинський та Микола Константинович були визнані такими особами, яким не можна дозволити видання та редагування будь-яких газет та журналів [20, c. 136-143].

Більше того, невдовзі офіційний Петербург знайшов привід, щоб взагалі усунути О. А. Тищинського від роботи в канцелярії Чернігівського губернатора та в «Черниговских Губернских Ведомостях». Офіційним приводом для цього стала публікація в «Особом прибавлении» замітки про народження на Пинщині якоїсь дивної дитини-каліки, в якій столичні можновладці побачили алегорію на царський уряд.

Однак Олександр Амфіанович не припинив громадської діяльності. Після звільнення 3 посади в канцелярії губернатора він відкрив у своєму помешканні приватну бібліотеку. Згодом О. А. Тищинський був серед найактивніших організаторів Чернігівської громадської книгозбірні, яка офіційно відкрилася 28 березня 1877 р. Головою цієї установи став Петро Червінський, секретарем - Софія Русова, а скарбником - Олександр Тищинський. Олександр Амфіанович збирав для книгозбірні потрібні кошти, жертвував свої книжки і діставав нові для поповнення фонду тощо, адже він надавав великого значення друкованому слову, прагнув ширити знання. Багато чернігівців виховалися на книгах з бібліотеки О.А. Тищинського. Ще однією справою українського народолюбця стало заснування в Чернігові книгарні $[17$, с. 163,$164 ; 10$, с. $464 ; 20$, с. $104 ; 18$, с. 53, 55].

Цікавою сторінкою громадської діяльності О. А. Тищинського стала його активна участь у Чернігівському земстві. Адже в 1874-1877, 1877-1880 та 1883-1886 рр. він тричі обирався повітовим гласним від Чернігова та Березного. Разом із тим у 18751876 та 1877-1880 pр. Олександр Амфіанович двічі обирався головою Чернігівського повітового земства [23, с. 278, 305-307].

С. Ф. Русова згадувала, що інтереси Чернігівського повіту становили зміст його життя. Як демократ і щирий українець, він гаряче відстоював інтереси свого рідного краю і на земських зборах, і перед усіма «помпадурами», тобто представниками консервативно-бюрократичного чиновництва. Олександра Амфіановича всі знали за непідкупність переконань і чесну працю в земстві. У 70-х рp. XIX ст. О. А. Тищинський перетворився на прогресивного земського діяча, який легальними засобами діяльності піклувався про розвиток народної освіти, охорони здоров'я, справедливу розкладку земських податків, стан протипожежних засобів, санітарії території, облаштування доріг тощо [17, с. $164 ; 10$, с. $465 ; 21$, с. 79,80$]$.

Олександр Амфіанович наполегливо опікувався поступом народної освіти. Відомий чернігівський земський діяч В. М. Хижняков згадував, що коли головою Чернігівської земської повітової управи став О. А. Тищинський, «збільшення числа шкіл пішло більш швидкими темпами». В 1876 р. були відкриті школи в Салтиковій Дівиці, Довжику, Андріївці, Ковчині, Горбові, Слабині і двокласна міністерська школа в Петрушині. У 1877 р. додалося училище в Куликівці. Усього ж якщо в 1876 р. в Чернігівському повіті функціонувало 13 шкіл, то в 1880 р. вже 20, а витрати на народну освіту збільшилися з 5800 крб до 9480 крб відповідно [23, с. 206, 207]. 
У 1875 р. Чернігівське повітове земство вперше рішуче взялося за організацію земської медицини. Відтоді щорічно створювалися медичні дільниці, збільшувалася кількість лікарів та фельдшерів, поліпшувалося постачання медикаментів тощо. Так, витрати на медицину в 1876 р. становили 8000 крб, а в 1879 р. - 14900 крб [23, с. 239]. Звісно, роль тодішнього голови Чернігівського повітового земства у розвитку охорони здоров'я була вельми важливою.

О. А. Тищинський мав усталене коло спілкування, до якого належали такі чернігівські діячі, як видатний український байкар Леонід Глібов; відомий земський діяч, член земської губернської управи, повітовий лікар Олександр Павлович Карпинський; член губернської управи, свідомий українець, член місцевої громади Микола Костантинович; земський лікар, демократ, який мав певні українські симпатії й переконання, Іван Федорович Рашевський; губернаторський урядовець, який допоміг українській справі заснування в місті музею Шевченка, Іван Григорович Рашевський; відомий земський статистик і український народолюбець Олександр Олександрович Русов; відомий український народолюбець Ілля Людвигович Шраг та ін. Всі ці діячі були тісно пов'язані особистими дружніми стосунками [17, с. 164-165].

Втім, народолюбна спрямованість діяльності Олександра Амфіановича викликала роздратування поміж земців-консерваторів, під тиском яких О.А. Тищинський був змушений покинути земство. Однак на останній своїй посаді товариша директора міського банку він продовжував допомагати селянам, залишаючись одним з найпопулярніших діячів серед простих людей чернігівського краю [10, с. 464 465].

У 1880-х - на початку 1890-х рр. О. А. Тищинський активно спілкувався з відомим українським байкарем Л. І. Глібовим, відвідував його щотижневі «четверги», де збиралася свідома українська інтелігенція. За умов, коли Леонід Іванович втратив зір, Олександр Амфіанович записував його тексти, популяризував їх. Він же опікувався 50-річним ювілеєм діяльності відомого байкаря у 1891 р., не покидав Л. І. Глібова до його кончини 29 жовтня 1893 р. [18, с. 53].

У 1893 р. Олександр Амфіанович разом із В. Т. Андрієвським, А. В. Верзілівим та І. Л. Шрагом відродив місцеву українську громаду, яка стала головним осередком української патріотичної інтелігенції у справі національнокультурного відродження у краї. Жодна громадівська справа не обходилася без його дієвої участі [10, с. 463,465$]$.

О.А. Тищинський належав до найпомітніших постатей в Чернігівській українській громаді, був знаним і користувався довірою й авторитетом в українському національному русі кінця XIX ст. Підтвердженням цього є листи одного з ідейних лідерів українського руху зазначеної доби Олександра Кониського до керівника Чернігівської української громади Іллі Шрага. Починаючи від 1893 р. до 1896 р., О. Я. Кониський неодноразово з великою повагою згадував Кума, як він називав О. А. Тищинського. Листи Олександра Яковича свідчать, що він добре знав Олександра Амфіановича і прагнув залучити його до участі у своїх письменницьких або видавничих справах, коли йшлося про підготовку або видання творів; навіть у таких делікатних справах, як передача заповіту в Чернігівський громадський міський банк, де О. А. Тищинський працював у той час заступником директора $[15$, с. 50-52, 56-59, 62-63, 73, 74, 81, 83, 84, 92, 104, 105, 109 , $112,116,120]$.

Судячи із вказаного листування, О. А. Тищинський, поряд з іншими провідними діячами Чернігівської української громади, зокрема В. Т. Андрієвським, Б. Д. Грінченком, В. І. Самійленком, І. Л. Шрагом, був бажаним гостем у середовищі київських громадян, оскільки належав «до нашої братії». Прикметно, що О. Я. Кониський та й інші діячі Київської громади запрошували О. А. Тищинського на захист магістерської дисертації Михайла Грушевського, призначений на 22 травня 1894 p. $[15$, с. $65,66,77,78,95,96]$.

Олександр Амфіанович був батьком великої родини. У шлюбі з миловидною 3. Дельмас, яка мала французьке етнічне коріння, народилося семеро дітей. Найбільшою 
гордістю стала наймолодша донька Любочка. Вихована українському дусі, вона завше співала в українському хорі, ходила в українському вбранні, а з часом стала відомою співачкою Л. О. Андреєвою-Дельмас [21, с. 79, 80].

Смерть Олександра Амфіановича Тищинського 28 січня 1896 р. приголомшила О.Я. Кониського, який більше тижня ходив «наче в хмарі, наче придавлений і роздавлений!». «Велика шкода для Чернігова!..» - писав він під враженням «несподівано-наглого нещастя», яким стала смерть «незабутнього до віку Кума» [15, c. $131 ; 21$, c. 80$]$.

Висновки. Отже, формування світогляду Олександра Тищинського відбувалося під впливом кількох важливих ідейних чинників, зокрема ліберальних ідей оновлення суспільства на основі утвердження конституційного способу правління; поглядів радикальної демократії, які популяризувалися «Колоколом» О. І. Герцена та М. П. Огарьова; українських народолюбних впливів, які спричинили формування зацікавленості українським фольклором і письменством, а особливо поезією Тараса Шевченка. Діяльність О. А. Тищинського як українського народолюбця зародилася в період його участі в Харківсько-Київському таємному товаристві (1856-1860), а утвердилася на початку 1860-х рр. - у часи діяльності в Чернігівській українській громаді. Як український національний демократ, О. А. Тищинський займався педагогічною, публіцистичною та громадською національнокультурницькою діяльністю, хоча його радикально-демократичні симпатії обумовлювали зв'язки з російськими землевольцями. У 1870-1880-х рр. український діяч був серед найактивніших організаторів Чернігівської громадської книгозбірні та книгарні, відстоював інтереси народу в лавах Чернігівського повітового земства, сприяючи поступу народної освіти, охорони здоров'я тощо. У 1890-х рр. О. А. Тищинський входив до кола тих діячів, які відновили Чернігівську українську громаду. Олександр Амфіанович належав до найпомітніших й найавторитетніших українських народолюбців Чернігівщини, зробив свій вагомий внесок у розвиток українського національного культурництва в цьому краї.

\section{REFERENCES}

1. Gosudarstvennyy arkhiv Rossiyskoy Federatsii (GARF). F. 109, 1 eksp., 1860 g., d. 26, ch. I, lit. B (in Russian).

2. GARF. F. 109, 1 eksp., 1860 g., d. 26, ch. 5 (in Russian).

3. GARF. F. 109, 1 eksp., 1860 g., d. 26, ch. 5, lit. B (in Russian).

4. GARF. F. 109, 1 eksp., 1860 g., d. 26, ch. 7 (in Russian).

5. GARF. F. 109, 1 eksp., 1863 g., d. 97, ch. 70 (in Russian).

6. GARF. F. 109, op. 214, d. 133 (in Russian).

7. GARF. F. 112, op. 1, d. 72 (in Russian).

8. GARF. F. 112, op. 1, d. 73 (in Russian).

9. GARF. F. 112, op. 1, d. 74 (in Russian).

10. Hrinchenkova, Mariya i Verzyliv, Arkadiy (1928). Chernyhivs'ka Ukrayins'ka Hromada. Chernyhiv i pivnichne Livoberezhzhya: ohlyady, rozvidky, materiyaly [Chernihiv Ukrainian Community. Chernihiv and the northern Left Bank: reviews, explorations, materials] / pid red. akad. Mykh. Hrushevs'koho. Kyyiv: derzh. Vyd-vo Ukrayiny. S. 463-483 (in Ukrainian).

11. Dudko, V. (2006). «Ranniy» Oleksandr Tyshchyns'kyy: storinky zhyttya i tvorchosti [«Early» Alexander Tyshchinsky: pages of life and work.] Siveryans 'kyy litopys, № 6, s. 76-83 (in Ukrainian).

12. Efymenko Petr Savvych (Avtobyohrafycheskye zametky) [Efimenko Peter Savvich (Autobiographical notes)] (2009). V: Starykov H. M. Materialy do biohrafiy Petra ta Oleksandry Yefymenkiv. Sumskyy istoryko-arkhivnyy zhurnal. Vyp. VI-VII. S. $39-47$ (in Ukrainian).

13. Instytut rukopysu NBU NAN Ukrayiny. Viddil rukopysiv. F. 1, spr. 302 (in Ukrainian).

14. Koz'min, B. (1928). M. D. Muravskiy v Khar'kovskom taynom obshchestve 1856-1858 gg. [D. Muravsky in the Kharkov secret society 1856-1858]. Katorga i ssylka, № 4 (41), s. 125-139 (in Russian). 
15. Lysty Oleksandra Konys'koho do Illi Shraha [Letters of Alexander Konisky to Ilya Shrag] (2011) / uporyad., peredm., prym. T. P. Demchenko, O. O. Mysyury. Chernihiv: Prosvita, 210 s. (in Ukrainian).

16. Nechkina, M. V. (1980). «Zemlya i Volya» 60-kh godov XIX v. (Po sledstvennym materialam) [«Land and Freedom» of the 60s of the 19th century. (According to the investigative materials)]. Vstrecha dvukh pokoleniy. Iz istorii russkogo revolyutsionnogo dvizheniya kontsa 50-kh - nachala 60-kh godov XIX veka. Sb. st. Moskva: Izd-vo «Nauka», s. 287-319 (in Russian).

17. Rusova, Sofiya (1928). Moyi spomyny. 1861-1879 [My memories. 1861-1879]. Za sto lit, vyp. 2, s. 135-175 (in Ukrainian).

18. Samoylenko, H. V. (2011). Virnyy druh L. Hlibova O. Tyshchyns'kyy [L. Glibov's faithful friend O. Tyshchynsky]. Literatura ta kul'tura Polissya. Vyp. 63. Istoryko-kul'turnyy prostir ta yoho napovnennya okremymy yavyshchamy. Nizhyn: NDU im. M. Hoholya, s. 49-59 (in Ukrainian).

19. Samoylenko, H. V. (2010). Chernihivs'ka teatral'na trupa «Tovarystvo kokhayuchykh ridnu movu» [Chernihiv theater troupe «Society of native language lovers»]. Literatura ta kul'tura Polissya. Vyp. 60. Rehional'ni ta zahal'noukrayins'ki protsesy u suchasnomu doslidnyts'komu vymiri. Nizhyn: NDU im. M. Hoholya, s. 204-211 (in Ukrainian).

20. Syvachenko, M., Deko, O. (1969). Leonid Hlibov. Doslidzhennya i materialy [Leonid Glibov. Research and materials]. Kyyiv: Vyd-vo khud. liter., 288 s. (in Ukrainian).

21. Stud'onova, L. V. (2003). Chernihivs'ke povitove zemstvo: Storinky istoriyi [Chernihiv County Zemstvo: Pages of History]. Nizhyn: TOV «Aspekt-Polihraf, 88 s. (in Ukrainian).

22. Suspil'no-politychnyy rukh na Ukrayini v 1856-1862 rr. [Socio-political movement in Ukraine in 1856-1862] (1963) / redkol. tomu: V. Korolyuk, H. Marakhov, S. Pil'kevych, F. Shevchenko, E. Khalich. Kyyiv: Vyd-vo AN Ukrayins'koyi RSR, 388 s. (in Ukrainian).

23. Khyzhnyakov, Vasyl' (2016). Chernihivs'ka starovyna [Chernihiv antiquity] / do druku pidhot. Oleksandr Kovalenko, Andriy Kurdanov, Oleksandr Rakhno. Chernihiv: Vyd-vo «Desna Polihraf», 352 s. (in Ukrainian).

24. Sheveliv, Borys (1929). L. I. Hlibov i tyzhnevyk «Chernyhovskyy Lystok» u protsesi S. Nosa, I. Andrushchenka ta chynsh. 1863-1868 rr. [L. I. Glibov and the weekly «Chernihiv Leaf» in the process of S. Nos, I. Andrushchenko and chinsh. 1863-1868]. Za sto lit. Materiyaly z hromads'koho y literaturnoho zhyttya Ukrayiny XIX i pochatkiv XX stolittya / pid red. akad. Mykhayla Hrushevs'koho. Kyyiv: Derzh. vyd-vo Ukrayiny, kn. 4, s. 25-47 (in Ukrainian).

25. Sheveliv, Borys (1928). Tyzhnevyk «Chernyhovskyy Lystok» za redaktsiyeyu L. I. Hlibova (1861-1863 rr.) [Weekly «Chernihiv Leaf» edited by L. I. Glibov (1861-1863)]. Chernyhiv i pivnichne Livoberezhzhya: ohlyady, rozvidky, materiyaly / pid red. akad. Mykh. Hrushevs'koho. Kyyiv: Derzh. vyd-vo Ukrayiny. S. 443-462 (in Ukrainian).

26. Yastrebov, F. (1960). Revolyutsinnye demokraty na Ukraine. Vtoraya polovina 50-kh - nachalo 60-kh godov XIX st. [Revolutionary Democrats in Ukraine. Second half of the 50s - early 60s of the 19th century]. Kiev: Izd-vo AN Ukrainskoy SSR, 308 s. (in Russian).

Received 16.09.2020

Accepted 01.10.2020 